\title{
Persepsi Mahasiswa Tentang Penyelenggaraan Program Intensif Bahasa pada Pusat Pengembangan Bahasa
}

\author{
Yeti Nurizzati \\ IAIN Syekh Nurjati Cirebon \\ e-mail:yeti@syekhnurjati.ac.id
}

\begin{abstract}
Language Development Center (PPB) IAIN Syekh Nurjati Cirebon is one of the Technical Implementation Unit of higher education related to intensive English and Arabic development program. All students from semester one to four must follow and graduate on this program. Assessment of the implementation of this program based on student perceptions of 100 samples is an evaluative study conducted by researchers. Using a questionnaire as a research instrument, it contains input, process, output, lecturers and staff indicators in the learning process. From the research results obtained conclusion that the assessment of the implementation of language intensive program on PPB IAIN Syekh Nurjati Cirebon based on students' perceptions goes pretty well. Most of the students considered that the lecturers of PPB had prepared the teaching well, mastered the taught material, and the exam questions were in accordance with the taught material. Some things that need to be improved are intensive course lectures held on Saturday Sunday, late module distribution, team teaching implementation that has not been optimal, and poor lecturer behavior.
\end{abstract}

Keywords: Language intensive program, Perception 


\section{Pendahuluan}

Pola pikir masyarakat mengalami perubahan akan pentingnya pendidikan berakibat pada meningkatnya minat masyarakat untuk mengikuti pendidikan tinggi. Pendidikan tinggi dianggap sebagai tempat penghasil sumber daya manusia yang bermutu. Pada perkembangannya perguruan tinggi tidak hanya dilihat sebagai pusat ilmu pengetahuan, pusat penelitian, dan pusat pengabdian kepada masyarakat, tetapi sebagai suatu entitas korporat "penghasil ilmu pengetahuan" yang perlu bersaing untuk menjamin kelangsungan hidup. Perubahan ini dapat dilihat dari ketatnya persaingan kualitas layanan, harga, dan promosi perguruan tinggi. Persaingan yang semakin ketat dan tuntutan kebutuhan masyarakat akan kualitas yang berorientasi pada nilai pengguna jasa (customer value) menuntut perguruan tinggi untuk dapat menanggapinya dengan cepat (responsiveness). Oleh karena itu, hal utama yang harus diprioritaskan oleh perguruan tinggi adalah kepuasan mahasiswa.

Manajemen peningkatan mutu pendidikan tinggi diartikan sebagai layanan publik secara profesional yang dijalankan semaksimal mungkin untuk memberikan layanan yang sesuai standar bahkan melebihi standar. Artinya layanan yang diberikan perguruan tinggi harus berkualitas agar mendapatkan kepercayaan masyarakat atau publik melalui kepuasan mahasiswa sebagai pengguna utama. Kepuasan mahasiswa ini bisa dilihat dari hasil penilaian mahasiswa yang baik terhadap penyelenggaraan pendidikan tinggi tersebut.

Pusat Pengembangan Bahasa (PPB) IAIN Syekh Nurjati Cirebon merupakan salah satu Unit Pelaksana Teknis penyelenggaraan pendidikan tinggi berkaitan dengan program pengembangan bahasa Arab dan Inggris yang dilakukan secara intensif. Seluruh mahasiswa semester satu sampai empat harus mengikuti dan lulus pada program ini. Sebagai salah satu program unggulan, PPB hendaknya mampu menyelenggarakan program intensif bahasa dengan baik dan memuaskan mahasiswa.

Penelitian ini bertujuan untuk mengetahui bagaimanakah penilaian mahasiswa berdasarkan persepsinya terhadap penyelenggaraan program intensif bahasa pada PPB, inilah pertanyaan utama yang akan dikaji. Penilaian mahasiswa ini 
lebih difokuskan pada input pembelajaran, proses pembelajaran, output pembelajaran, dosen, serta staff pengelola PPB.

\section{Pendidikan}

Menurut Kamus Besar Bahasa Indonesia (2008: 326), "Pendidikan adalah proses perubahan sikap dan tata laku seseorang atau kelompok orang dalam usaha mendewasakan manusia melalui upaya pengajaran dan pelatihan". Sesuai dengan Undang Undang Republik Indonesia No. 20 tahun 2003 Tentang Sistem Pendidikan Nasional Bab 1 ayat 1, yaitu: Pendidikan adalah usaha sadar dan terencana untuk mewujudkan suasana belajar dan proses pembelajaran agar peserta didik secara aktif mengembangkan potensi dirinya untuk memiliki kekuatan spiritual keagamaan, pengendalian diri, kepribadian, kecerdasan, akhlak mulia, serta keterampilan yang diperlukan dirinya, masyarakat, bangsa dan negara.

Kegiatan penyelenggaraan pendidikan mulai dari tingkat dasar sampai dengan perguruan tinggi pada dasarnya adalah kegiatan atau industri jasa, yaitu memberikan layanan jasa pendidikan kepada murid / siswa sebagai pelanggan (customers).

Menurut Rambat Lupiyoadi (2008: 148) bahwa hal-hal yang harus diperhatikan pada karakteristik jasa perguruan tinggi antara lain:1) perguruan tinggi termasuk dalam kelompok jasa murni, dimana pemberian jasa yang dilakukan di dukung alat kerja atau sarana pendukung semata. Contoh: ruang kelas, kursi, meja, buku-buku, dan lain-lain. 2) jasa yang diberikan membutuhkan kehadiran pengguna jasa (mahasiswa), yang dalam hal ini pelanggan yang mendatangi lembaga pendidikan tersebut untuk mendapatkan jasa yang diinginkan (meski dalam perkembangannya ada juga yang menawarkan program universitas terbuka, kuliah jarak jauh (distance learning) dan lain-lain) penerima jasanya adalah orang, jadi merupakan pembelian jasa yang berbasis orang. Atau dalam jasa biasa disebut sistem kontrak tinggi (high contract system), yaitu hubungan antara pemberi jasa dengan pelanggan tinggi. Pelanggan dan penyedia jasa terus berinteraksi selama proses pemberian jasa berlangsung. Dengan kata lain, untuk menerima jasa pelanggan harus menjadi bagian dari system jasa tersebut) hubungan dengan pelanggan berdasarkan 
hubungan keanggotaan (member relationship), dimana pelanggan telah menjadi anggota lembaga pendidikan tertentu. Sistem pemberian jasanya dilakukan secara terus-menerus dan teratur sesuai kurikulum yang telah ditetapkan.

Hal pokok yang terdapat pada manajemen mutu terpadu pendidikan tinggi adalah perbaikan secara terus-menerus (continuous improvement). Konsep ini mengandung pengertian bahwa pihak pengelola pendidikan selalu melakukan berbagai perbaikan dan peningkatan secara terus menerus untuk menjamin semua komponen penyelenggaraan pendidikan telah mencapai standar mutu yang ditetapkan. Ini berarti bahwa pendidikan harus memperhatikan perkembangan tuntutan dan kebutuhan pelanggan, dalam hal ini disebut sebagai standar mutu (quality assurance). Standar mutu pendidikan tinggi misalnya berupa akuisisi kemampuan dasar bidang pembelajaran, kurikulum, dan standar evaluasi layanan. Hal yang penting lainnya adalah memperjelas apa yang ditawarkan institusi dan apa yang diharapkan mahasiswa (Edward Sallis, 2006:83).

Fornell (1992) dalam bukunya Fandy Tjiptono (2011:433) bahwa "Kepuasan merupakan evaluasi purna beli keseluruhan yang membandingkan persepsi kinerja produk dengan ekspektasi pra pembelian”. Mowen (1995) dalam FandyTjiptono, merumuskan "Kepuasan pelanggan sebagai sikap keseluruhan terhadap suatu barang atau jasa setelah perolehan (acquisition) dan pemakaiannya" (2011: 434). Dengan kata lain, kepuasan pelanggan merupakan penilaian evaluatif purna beli yang dihasilkan dari seleksi spesifik.

Berdasarkan beberapa definisi tersebut maka dapat diambil kesimpulan bahwa kepuasan pelanggan adalah respon (baik respon emosional maupun kognitif) atau penilaian dari evaluasi yang dilakukan oleh pelanggan dengan membandingkan persepsi terhadap kinerja/kualitas produk dengan harapan yang akan diterimanya bila ia membeli atau mengkonsumsi suatu produk atau jasa. Dalam penelitian ini kepuasan mahasiswa merupakan respon atau penilaian dari evaluasi yang dilakukan oleh mahasiswa dengan membandingkan persepsi mahasiswa dengan harapan mahasiswa terhadap penyelenggaraan pendidikan.

Beberapa upaya yang dapat diaplikasikan untuk menjaga layanan jasa dalam penyelenggaraan pendidikan tinggi yang bersifat people- based service ialah: 
Pertama, melakukan investasi dalam proses rekruitmen, seleksi, pemotivasian, pelatihan dan pengembangan karyawan. Melalui upaya tersebut lembaga pendidikan akan memiliki tenaga guru yang profesional, kompeten serta mampu memberikan layanan yang terbaik. Memiliki tenaga kependidikan sebagai penunjang yang memiliki keterampilan dan kemampuan memadai, memiliki motovasi tinggi serta senantiasa dapat mengembangkan kemampuannya sesuai dengan tuntutan kebutuhan. Kedua, melakukan standarisasi proses pelaksanaan jasa (service performance process standardization) atau industrialisasi jasa dengan cara mempromosikan programprogram pendidikan, meningkatkan kualifikasi dan profesionalisme tenaga pengajar, mendorong peningkatan jumlah tenaga guru besar dan kepakaran melalui penelitianpenelitian dalam bidang pendidikan. Program yang tengah dikembangkan di lembaga pendidikan untuk menetapkan standar layanan antara lain melalui kegiatan penyusunan Standar Operational Prosedur (SOP) sebagai salah satu kegiatan dalam program Satuan Penjaminan Mutu. Setiap aspek kegiatan yang dilakukan dalam penyelenggaraan pendidikan, masing-masing memiliki SOP yang memiliki indikator mutu, dengan demikian satuan pendidikan memiliki ciri mutu dengan standar baku yang jelas.

Ketiga, melakukan service customization, meningkatkan interaksi antara lembaga pendidikan dengan masyarakat serta dunia kerja sehingga apa yang diproduksi dalam dunia pendidikan sesuai dengan kebutuhan masyarakat dan lapangan kerja. Keterkaitan dan kesepadanan antara produk pendidikan dengan tuntutan kebutuhan menjadi aspek utama sehingga lulusan satuan pendidikan langsung diterima oleh masyarakat atau dunia kerja. Service customization berhubungan erat dengan customers satisfaction, apa yang dihasilkan oleh lembaga pendidikan sesuai dengan harapan masyarakat. Lulusan pendidikan siap pakai menjadi tujuan lembaga pendidikan, oleh karena itu pendidikan harus berorientasi kepada kebutuhan dan tuntutan perkembangan teknologi, dalam kontreks ini pula lembaga pendidikan melakukan upaya penyesuaian kurikulum serta kebijkan lain yangberhubungan dengan kesesuaian pendidikan dengan kebutuhan, seperti misalnya kebutuhan lokal yang diantisipasi melalui kurikulum muatan lokal. Keempat, melakukan treacer study, monitoring kepuasan pelanggan, baik secara pasif maupun 
dengan penelitian dan survey ke lapangan. Cara ini efektif untuk melihat kondisi para alumni atau lulusan di lapangan, sehingga dapat memberikan feed back untuk melakukan perbaikan kurikulum maupun pembukaan program studi yang dibutuhkan oleh masyarakat. Aspek ini masih berkaitan dengan customers satisfaction, hasil pendidikan yang sesuai dengan kebutuhan. Oleh karena itu, lembaga pendidikan perlu melakukan upaya monitoring kebutuhan dan kepuasan pelanggan-tentang sejauhmana hasil pendidikan dapat diaplikasikan dalam duniakerja atau dalam kehidupan sehari-hari. Survey lapangan untuk memastikan keterkaitan dengan kebutuhan sekaligus menjaring masukan-sesuatu yang baru dan dibutuhkan oleh masyarakat. Menjawab kebutuhan dan antisipasi perkembangan umumnya dilakukan dengan melalui inovasi-inovasi pendidikan. (Yahya Sudarya, 2007)

\section{Metode Penelitian}

Penelitian ini merupakan studi analisis terhadap program intensif bahasa pada Pusat Pengembangan Bahasa (PPB) IAIN Syekh Nurjati Cirebon. Sampel penelitian adalah mahasiswa yang telah mengikuti program intensif bahasa (Arab maupun Inggris) dimana sampel dipilih secara acak (random) pada bulan Juni tahun 2016 sebanyak seratus orang.

Instrumen penelitian berupa angket berisi pernyataan-pernyataan menggunakan skala likert dengan skala 1-4. Skor 1 kategori sangat tidak setuju, 2 tidak setuju, 3 setuju, dan 4 sangat setuju. Jumlah pernyataan sebanyak 22 butir terdiri dari 2 butir tentang input pembelajaran, 6 butir tentang proses pembelajaran, 10 butir tentang dosen, 2 butir tentang staf, dan 2 butir tentang output pembelajaran.

Tiap-tiap butir angket yang telah dijawab kemudian diskor dan dihitung prosentase masing-masing. Rumus prosentase $P=\frac{f}{n} x 100 \%$. Adapun interpretasi prosentase adalah sebagai berikut:

$$
\begin{array}{ll}
100 \% & =\text { Seluruhnya } \\
90 \%-99 \% & =\text { Hampir Seluruhnya } \\
80 \%-89 \% & =\text { Sebagian Besar } \\
51 \%-79 \% & =\text { Lebih dari Setengahnya } \\
50 \% & =\text { Setengahnya }
\end{array}
$$




$$
\begin{array}{ll}
40 \%-49 \% & =\text { Hampir Setengahnya } \\
10 \%-39 \% & =\text { Sebagian Kecil } \\
1 \%-9 \% & =\text { Sedikit Kecil } \\
0 \% & =\text { Tidak Ada Sama Sekali }
\end{array}
$$

(Anas Sudijono, $2003: 40$ )

Sedangkan arti dari prosentase menurut Arikunto (2006: 109) adalah:

$$
\begin{array}{ll}
86 \%-100 \% & =\text { Sangat Baik } \\
76 \%-85 \% & =\text { Baik } \\
60 \%-75 \% & =\text { Cukup Baik } \\
55 \%-59 \% & =\text { Kurang Baik }
\end{array}
$$

Kurang dari $54 \% \quad=$ Sangat Kurang Baik

\section{Hasil Penelitian}

Unit Pelaksana Teknis (UPT) Pusat Pengembangan Bahasa (PPB) IAIN Syekh Nurjati Cirebon dipimpin oleh Dr. H. Edy Setyawan, Lc., M.A. Adapun Visi PPB adalah menjadi pusat pengembangan bahasa yang profesional, kreatif dan inovatif yang dibangun atas dasar komitmen bersama yang kokoh dalam upaya mewujudkan program unggulan IAIN menuju tercapainya harapan menjadi UIN Cirebon yang mempertahankan identitas keislaman melalui penguasaan bahasa asing. Sedangkan misi PPB adalah :

1. mengantarkan mahasiswa memiliki alat untuk menggali, menguasai dan mengembangkan ilmu-ilmu keislaman melalui penguasaan bahasa arab dan inggris;

2. memberikan pelayanan bahasa kepada mahasiswa, dosen, dan karyawan secara profesional dan proporsional;

3. mengembangkan dan melakukan penelitian bidang kebahasaan secara kontinu baik yang berkaitan dengan materi, media, strategi pembelajaran dan profesionalitas pengajar bahasa dalam upaya mewujudkan pembelajaran bahasa arab dan inggris yang efektif, efisien dan menyenangkan;

4. meningkatkan kualitas pengajar bahasa melalui pelatihan dan workshop. 
Pembelajaran bahasa yang dikelola oleh PPB IAIN Syekh Nurjati Cirebon diformulasikan dalam pola intensif dengan ketentuan sebagai berikut:

1. Program pembelajaran Bahasa Arab intensif merupakan pengganti salah satu MK komponen MKU yaitu MK Bahasa Arab I dan II masing-masing sebesar 4 sks; dilaksanakanselama 1 tahun (semester I dan II);

2. Program pembelajran Bahasa Inggris intensif merupakan pengganti salah satu MK komponen MKU yaitu MK Bahasa Inggris I dan II masing-masing sebesar 4 sks; dilaksanakan selama 1 tahun (semester III dan IV);

3. Diadakan placement test untuk menentukan pembagian kelompok dan mempermudah pelaksanaan PBM;

4. Kelas dibagi dalam kelompok kecil terdiri dari 20-25 orang per kelas secara lintas jurusan, sesuai hasil placement test;

5. Program bahasa arab dan inggris dilaksanakan selama 4 pertemuan tiap minggu selama dua hari (sabtu, minggu) sehingga dalam 1 semester jumlah pertemuan sebanyak 64-70 pertemuan;

6. Tenaga pendidik yang mengajar adalah tim dosen luar biasa/ tutor dari PPB;

7. Diupayakan tidak ada kelas kosong (karena tidak ada dosen), karena PPB menyiapkan dosen piket;

8. Bagi mahasiswa yang gagal (belum lulus) pada Bahasa Arab I (semester I), Bahasa Arab II (semester II), Bahasa Inggris I (semester III) dan Bahasa Inggris II (semester IV), UPT PPB memberi kesempatan untuk mengikuti pembelajaran tambahan sebanyak 15-20 kali tatap muka yang dilaksanakan pada semester antara;

9. Bagi mahasiswa yang lulus Bahasa Arab I (semester I), Bahasa Arab II (semester II), Bahasa Inggris I (semester III) dan Bahasa Inggris II (semester IV), akan diuji TOEFL dan TOAFL dan kepada yang bersangkutan akan diberikan sertifikat.

Materi yang digunakan dalam bahasa arab adalah modifikasi dari buku Alarabiyah li al-Nasyi'in jilid 1-4, dan Al-arabiyah bain yadaik jilid 1-2 ditambah materi qira'at al-Qur'an. Sedangkan materi yang digunakan dalam bahasa inggris adalah ramuan dari buku Learn to speak english dan Fundamental of english grammar, say the right thing! : a functional approach to developing speaking skill, 
english grammar in use, exercises in verb patterns, guide to patterns ang usages in english, etc.

Evaluasi (ujian) dilaksanakan secara integral untuk semua jenis kemahiran bahasa, untuk semua peserta dengan model yang sama pada kompetensi kebahasaan sesuai dengan levelnya, dan diberikan dalam bentuk lisan dan tulisan. Ujian dilakukan dua kali per semester yaitu pada uji kompetensi I dan II (UK I dan II). Yang berhak mengikuti ujian adalah mahasiswa yang kehadirannya tidak kurang dari 75\%; apabila kurang dari 75\% maka mahasiswa tersebut tidak berhak mengikuti ujian dan dianggap tidak mengambil MK bahasa arab atau inggris. Nilai akhir adalah gabungan dari hasil UAS, UTS, kreatifitas kelas dan wajib manzili (homework) dengan prosentase penilaian adalah kehadiran 5\%, kreativitas kelas $10 \%$, uji kompetensi I 25\%, uji kompetensi II 50\%, wajib manzili (homework) 10\%.

Intensifikasi Bahasa Arab dan Inggris diarahkan untuk membekali mahasiswa agar memiliki:

1. Keterampilan komunikasi pasif, mampu mendengarkan pembicaraan dan memahami naskah ilmiah dan profesi sesuai dengan bidangnya;

2. Keterampilan komunikasi aktif, mampu mengungkapkan secara lisan dan tulisan dalam lingkup bidang ilmiah dan profesinya.

Setelah mengikuti program pembelajaran bahasa arab intensif, mahasiswa diharapkan dapat menguasai sekitar 4000 mufradat baik yang sederhana maupun kompleks dalam \pm 250 pola kalimat (tarakib) dan peristilahan ('ibarat ishtilahiyah) yang diprogramkan, serta memiliki pengetahuan keterampilan kebahasaan pada tingkat menengah (mustawa mutawasith). Sedangkan setelah mengikuti program pembelajaran bahasa inggris intensif, mahasiswa diharapkan dapat menguasai sekitar 4000 vocabulary (kosa kata) baik yang sederhana maupun kompleks dalam pola-pola kalimat dari 16 tenses dan pola-pola kalimat lainnya berdasarkan unsur-unsur pembentuknya dan menguasai peristilahan (terminology) yang diprogramkan serta memiliki pengetahuan keterampilan dan kebahasaan pada tingkat menengah (intermediate). 


\section{Persepsi Mahasiswa terhadap Penyelenggaraan Program Intensif Bahasa pada PPB}

Berikut ini adalah hasil penilaian seratus mahasiswa terhadap program intensif bahasa pada PPB:

1. Input Pembelajaran

a. Lebih dari setengahnya mahasiswa (65\%) menilai bahwa informasi tentang program intensif dimengerti mahasiswa dengan baik sebelum perkuliahan dimulai.

b. Lebih dari setengahnya mahasiswa (76\%) menganggap bahwa perkuliahan pada hari Sabtu dan Minggu bukanlah perkuliahan yang efektif dilakukan.

2. Proses pembelajaran

a. Lebih dari setengahnya mahasiswa (54\%) menyatakan bahwa pengelompokan kelas intensif sudah efektif dilakukan.

b. Lebih dari setengahnya mahasiswa (61\%) menyatakan bahwa modul tidak dibagikan sebelum perkuliahan dimulai.

c. Lebih dari setengahnya mahasiswa (63\%) berpendapat bahwa materi modul pembelajaran mudah dipahami.

d. Lebih dari setengahnya mahasiswa (56\%) menganggap bahwa kurikulum dan target pembelajaran program intensif sudah jelas.

e. Setengahnya mahasiswa $(50 \%)$ berpendapat bahwa sistem team teaching adalah sistem yang efektif diterapkan pada proses perkuliahan, namun setengahnya lagi menyatakan hal sebaliknya.

f. Lebih dari setengahnya mahasiswa (72\%) mengatakan bahwa pengelola PPB menyediakan dosen pengganti apabila ada dosen yang berhalangan hadir.

3. Dosen PPB

a. Lebih dari setengahnya mahasiswa (78\%) menyatakan bahwa dosen PPB datang tepat waktu dan dapat mengelola waktu dengan baik.

b. Lebih dari setengahnya mahasiswa (74\%) menyatakan bahwa kontrak kuliah sudah disampaikan dengan jelas oleh dosen PPB.

c. Sebagian besar mahasiswa (81\%) menilai bahwa dosen PPB telah mempersiapkan pengajaran dengan baik. 
d. Sebagian besar mahasiswa (87\%) menyatakan bahwa dosen PPB menguasai materi yang diajarkan.

e. Lebih dari setengahnya mahasiswa (51\%) menyatakan bahwa dosen PPB menyampaikan materi dengan jelas.

f. Lebih dari setengahnya mahasiswa (52\%) menyatakan bahwa dosen PPB mampu mengelola dan mempersiapkan kelas dengan baik.

g. Sebagian besar mahasiswa (86\%) menyatakan bahwa soal ujian yang diberikan dosen PPB sesuai dengan materi yang diajarkan.

h. Lebih dari setengahnya mahasiswa (74\%) mengatakan bahwa penilaian perkuliahan diberikan secara transparan dan objektif oleh dosen PPB.

i. Lebih dari setengahnya mahasiswa (54\%) menilai bahwa dosen PPB kurang memberikan contoh yang baik dalam bersikap dan berperilaku.

j. Lebih dari setengahnya mahasiswa (72\%) mengatakan bahwa dosen PPB memberikan umpan balik kepada mahasiswa.

4. Staff PPB

a. Lebih dari setengahnya mahasiswa (74\%) mengatakan bahwa staff PPB memiliki kemampuan (skill dan pengetahuan) dalam melayani keperluan mahasiswa.

b. Lebih dari setengahnya mahasiswa (72\%) mengatakan bahwa staff PPB bersikap responsif (tanggap) dalam melayani keperluan mahasiswa.

5. Output Pembelajaran

a. Lebih dari setengahnya mahasiswa (71\%) mengatakan bahwa mahasiswa merasa puas terhadap program intensif bahasa yang dikelola PPB.

b. Lebih dari setengahnya mahasiswa (57\%) mengatakan bahwa mahasiswa mengalami peningkatan keterampilan berbahasa setelah mengikuti program intensif bahasa.

Prosentase yang diperoleh masing-masing item kemudian direkap untuk diperoleh rata-ratanya. 
Persepsi Mahasiswa Tentang Penyelenggaraan Program Intensif Bahasa pada Pusat Pengembangan Bahasa

Tabel 1. Rekapitulasi Penilaian Mahasiswa terhadap

Penyelenggaraan Program Intensif Bahasa PPB

\begin{tabular}{|c|c|c|c|c|}
\hline No Item & STS & TS & $\mathbf{S}$ & SS \\
\hline 1 & 4 & 31 & 57 & 8 \\
\hline 2 & 35 & 41 & 22 & 2 \\
\hline 3 & 19 & 42 & 28 & 11 \\
\hline 4 & 6 & 40 & 49 & 5 \\
\hline 5 & 3 & 41 & 51 & 5 \\
\hline 6 & 4 & 22 & 65 & 9 \\
\hline 7 & 11 & 39 & 42 & 8 \\
\hline 8 & 4 & 33 & 54 & 9 \\
\hline 9 & 4 & 15 & 71 & 10 \\
\hline 10 & 7 & 41 & 41 & 11 \\
\hline 11 & 2 & 12 & 73 & 13 \\
\hline 12 & 3 & 10 & 70 & 17 \\
\hline 13 & 10 & 44 & 35 & 11 \\
\hline 14 & 5 & 17 & 63 & 15 \\
\hline 15 & 9 & 40 & 48 & 3 \\
\hline 16 & 5 & 23 & 62 & 10 \\
\hline 17 & 5 & 23 & 67 & 5 \\
\hline 18 & 3 & 23 & 65 & 9 \\
\hline 19 & 3 & 25 & 63 & 9 \\
\hline 20 & 2 & 41 & 53 & 4 \\
\hline 21 & 7 & 19 & 68 & 6 \\
\hline 22 & 4 & 25 & 65 & 6 \\
\hline Total & 155 & 647 & 1212 & 186 \\
\hline Rata-rata & 7.05 & 29,41 & 55,09 & 8,45 \\
\hline
\end{tabular}

Berdasarkan tabel di atas, rekapitulasi hasil penilaian mahasiswa diperoleh rata-rata prosentase sebesar $63,55 \%$ (kategori cukup baik). Artinya bahwa penyelenggaraan program intensif bahasa yang dilakukan PPB berdasarkan persepsi mahasiswa sudah berjalan dengan cukup baik. Hal ini dilihat dari penilaian mahasiswa yang menyatakan setuju dan sangat setuju dalam persen. 


\section{Keunggulan dan Kekurangan Penyelenggaraan Program Intensif Bahasa pada PPB}

Program intensif bahasa pada PPB secara umum sudah berjalan baik, dimana mahasiswa merasa puas dan mengalami peningkatan keterampilan berbahasa; namun ada beberapa hal yang masih dinilai kurang oleh mahasiswa. Adapun keunggulan yang dimiliki PPB adalah:

1. Informasi mengenai program intensif bahasa oleh PPB sudah tersosialisasi dengan baik kepada mahasiswa

2. Pengelompokan kelas berdasarkan grade hasil tes penempatan efektif dilakukan

3. Materi modul mudah dipahami mahasiswa

4. Kurikulum dan target pembelajaran jelas

5. Tersedianya dosen pengganti apabila ada dosen yang berhalangan hadir

6. Dosen datang on time dan mengelola waktu dengan baik

7. Kontrak kuliah disampaikan dengan jelas saat awal tatap muka di kelas.

8. Materi pengajaran sudah disiapkan dengan baik

9. Dosen menguasai materi dan mampu menyampaikannya dengan jelas

10. Dosen PPB cukup mampu mengelola kelasnya dengan baik

11. Soal ujian yang diberikan sesuai dengan materi yang diajarkan

12. Penilaian diberikan secara transparan dan objektif

13. Dilakukan umpan balik di setiap ahir perkuliahan

14. Staff PPB memiliki pengetahuan dan keterampilan yang baik, juga tanggap dalam melayani keperluan mahasiswa

Sedangkan kekurangannya dalam hal:

1. Perkuliahan di hari Sabtu dan Minggu dipandang kurang efektif

2. Modul belum dibagikan kepada mahasiswa saat perkuliahan pertama kali dimulai

3. Sistem pembelajaran menggunakan team teaching kurang optimal dilakukan

4. Perilaku dosen PPB belum bisa menjadi teladan bagi mahasiswa

Mengacu pada kekurangan yang ada, maka pihak PPB hendaknya mulai mengupayakan agar perkuliahan program intensif dilakukan di hari Senin-Jumat, sama seperti jadwal mata kuliah yang lain. Pihak institusi, dalam hal ini IAIN Syekh 
Nurjati Cirebon sekarang sudah menambah gedung perkuliahan baru dan gedung laboratorium pendidikan, yang dapat dijadikan sebagai gedung alternatif bagi perkuliahan intensif ini.

Modul hendaknya sudah siap cetak dan dapat dibagikan kepada mahasiswa di awal pertemuan saat kontrak kuliah dilakukan. Oleh karena itu, dosen dan penerbit harus berkoordinasi dengan baik agar modul sudah selesai dan cetak lebih awal. Sistem pengajaran menggunakan team taching belum efektif dilakukan, karena kurangnya koordinasi antar dosen. Adanya pengulangan materi, dan pembawaan dosen yang berbeda seringkali membuat mahasiswa menjadi kurang nyaman dalam belajar. Oleh karena itu, diperlukan pertemuan antar dosen yang lebih intensif agar terjalin tim yang lebih baik.

Dosen hendaknya dapat menjaga perilakunya saat di kelas. Sikapnya yang kurang baik menjadi contoh yang kurang baik bagi mahasiswa. Tegurlah mahasiswa dengan kata-kata yang sopan, hindari main tangan kepada mahasiswa yang tidak bisa diatur, tidak merokok di kelas dan perilaku baik lainnya. Mulailah dari diri sendiri, barulah orang lain akan mengikuti.

\section{Kesimpulan}

Berdasarkan hasil penelitian dan pembahasan, maka dapat ditarik kesimpulan bahwa analisis penyelenggaraan program intensif bahasa pada PPB IAIN Syekh Nurjati Cirebon berdasarkan persepsi mahasiswa berjalan cukup baik. Sebagian besar mahasiswa menilai bahwa dosen PPB telah mempersiapkan pengajaran dengan baik, menguasai materi yang diajarkan, dan soal ujian sesuai dengan materi yang diajarkan.

Beberapa hal yang perlu diperbaiki adalah jadwal perkuliahan program intensif yang dilaksanakan pada hari sabtu minggu, pembagian modul yang terlambat, pelaksanaan team teaching yang belum optimal, dan perilaku dosen yang kurang baik. 


\section{Daftar Pustaka}

Arikunto, Suharsimi. 2006. Prosedur Penelitian: Suatu Pendekatan Praktik. Jakarta: Rineka Cipta.

Edward, Sallis. 2006. Total Quality Manajemen In Education. Yogyakarta:IRCiSoD.

Fandy, Tjiptono. 2011. Manajemen Jasa. Yogyakarta : Penerbit Andi.

Iskandar. 2009. Metodologi Penelitian Pendidikan dan Sosial (Kuantitatif dan Kualitatif). Jakarta: GP Press.

Lupiyoadi, Rambat. 2008. Manajemen Pemasaran Jasa Teori dan Pratik. Jakarta: Salemba Empat.

Setyawan, Edy. 2016. Profil Unit Pelaksana Teknis (UPT) Pusat Pengembangan Bahasa (PPB) IAIN Syekh Nurjati Cirebon. Buletin Smart Campus IAIN Syekh Nurjati Cirebon Vol IV Edisi Oktober-Desember.

Sudijono, Anas. 2003. Pengantar Statistik Pendidikan. Jakarta: Raja Grafindo Persada.

Sudarya, Yahya. 2007. Service Quality Satisfaction dalam Layanan Pendidikan: Kajian Teoritis. Jurnal Pendidikan Dasar. Nomor 
156 Yeti Nurizzati

Persepsi Mahasiswa Tentang Penyelenggaraan Program Intensif Bahasa pada Pusat Pengembangan Bahasa 